\title{
Exchange Rate Risk in the Foreign Exchange Market: A Challenge on Corporate Profitability
}

\author{
P. Sivarajadhanavel and Dr.S. Chandrakumaramangalam
}

\begin{abstract}
Foreign exchange market is the largest traded market across the globe. In India, foreign exchange market opened for trade during the decade of 1970's and most of the transaction done through banks. Many companies in India emerged as a global player during this period, but they need to face the exchange rate risk of volatility in the global trade as the exchange rate against US dollar has raised five folds during this period. Importantly the risk exposure of Indian companies to its foreign trade has also increased dramatically. Conceptually the foreign exchange market faces risks of transaction exposure, translation exposure, and operating exposure which seems to be part of the exchange rate determination system. The hedging measures to be part of the risk management practices in the foreign exchange system across the global market. The exchange currency of US dollar is taken in the account of the foreign exchange market and its impact corporate profitability is being discussed with reference to information technology major Infosys. As exchange rate has challenged Indian corporate at many periods of interval, due to volatile movement of exchange rate directly impact on the corporate profitability. Infosys risk hedging being analyzed to know how it manages the exchange risk volatility and impact on corporate profitability is studied reference to information technology (IT) industry. The historical picture of the exchange rate of INR against major currencies like US dollar, Euro, Pound sterling, and Yen, surprised many corporate as it had direct impact on the corporate profit. This paper brings out the problem of exchange rate risk and its effect on corporate profitability on IT industry.
\end{abstract}

Keywords --- Corporate Profitability, Exchange Rate, Foreign Exchange Market, Risk, Volatility

\section{INTRODUCTION}

$\mathrm{G}$ LOBAL foreign exchange market is the largest traded market in terms of trade volume, value, volatility and risk management. A foreign exchange system was considered to be a nascent market during the pre-liberalization period of India. Global market has seen many challenges after breakup in Bretton Woods administered fixed exchange rate system in

P. Sivarajadhanavel, Assistant Professor, School of Management Studies, Kongu Engineering College, Perundurai, Erode, TamilNadu, India. E-mail: sivarajadhanavel@gmail.com

Dr.S. Chandrakumaramangalam, Professor, School of Management Studies, Anna University of Technology, Coimbatore. E-mail: ckmaucbe@gmail.com

DOI: 10.9756/BIJIEMS.1403
1971[1]. Due to this market determined exchange rate system was introduced in 1972. In the market based exchange rate determined system there was more fluctuation in the exchange rate around the global markets due to increased effect of inflation, interest rate changes, oil price shock, political tension between Middle East countries, and Asian crises. Corporates at global level needs to go through these challenges in their cross broader trade activities as the means of impact on their profitability.

Indian foreign exchange market had similar situation as that of global market till pre-liberalization of economy. Postliberalization of an economy has brought significant changes in the exchange rate system during 1990s through monetary policy reforms. Till February 1992, Reserve Bank of India (RBI) deemed to be a decision maker in fixing the exchange rate in the foreign exchange market in India. But the external pressure over the call money rate pressure had thereafter brought a dual exchange rate system in March 1992, which was famous said to be Liberalized Exchange Rate Management System (LERMS). Then Unified Exchange rate was introduced in 1st March 1993. Even today, RBI fixes the reference rate for the exchange of foreign currencies at the end of the everyday.

The foreign exchange market faces the risks of transaction exposure, translation exposure, and operating exposure which seems to be part of the exchange rate determination. But these exchange rate movements had influenced over the corporate profitability. Firms in the international business needs to face the risks of exchange rate volatility over its import or export of raw materials, cash inflows and outflows of business transactions, which need to be managed at every level of its business operations. This paper brings out the problem of exchange rate risk and its effect on corporate profitability as major cause to be exchange rate scenario. The impact of foreign exchange rate movement on Indian IT (Information Technology) firms' revenue and its profitability is discussed in this paper. This would give wide representation of exchange rate impact on corporate profitable and strengthening the growth scenario of future IT businesses in India.

\section{FOREIGN EXCHANGE (FX) MARKET}

The FX market plays significant role in the global trade in determining the strength of an economy and its growth. World have moved into transition of foreign exchange practices after Bretton Woods in 1944, fixed to flexible exchange rate regime in 1972. During this period India has been following the global practices moving from peg exchange rate regime to floating rate exchange system and currently following market 
based exchange system. Even though, the Indian exchange rate is being controlled by Reserve Bank of India (RBI).

Global FX market comprises of the spot market, the forward market, the future market, and the options in the derivatives market segment. In India during August 2008 first foreign currency trading system was introduced against US dollar, then Euro, British Pound Sterling and Japanese Yen in the National Stock Exchange of India (NSE), later in the Multi-Commodity Exchange of India for currency trading (MCX-SX), and Bombay Stock Exchange of India (BSE). Now exclusive exchange started by BSE in the name of United Stock Exchange of India (USE)[4].

\section{FOREIGN EXCHANGE RATE RISK}

The risk of foreign exchange management is globally well understood by the practioners in the industry. Foreign exchange rate is unstable due to uncertainty over the interest rate, flow of capital from the foreign countries, recently problem of government policy and its uncertainty over the taxation of foreign fund flow. For the last two decades global foreign exchange rates amid volatility against most of the currencies, especially with the globally traded currency of US dollar and EURO which turned out to be more volatile due to financial risks which shadow on the economy growth. During this period Indian currency not left behind the global problems, as it needs to manage its exchange rate volatility risk against global currencies. Indian foreign exchange rate which depreciated the most reaching all time low of Rs.57.2165[2] against US dollar on 27th June 2012, due to the effect of global financial crisis in US, European slowdown, and high crude oil price. The depreciation of the Indian currency value had larger influence over the Indian corporate profitability for the firms depending upon import of resources from the foreign country by adding production cost and for an exporter it is said to be favour as rupee depreciates. But the risk of volatile exchange rate in the future market has its negative impact on fixing the exchange rate in the spot market, then covering the same in the futures market by the hedgers.

\section{HISTORICAL ForEIGN EXCHANGE RATE}

The historical trend of foreign exchange rate in India shows continuous depreciation of Indian rupee against the US dollar and other major currencies. Foreign exchange rate of Indian currency against US dollar shows that exchange rate was only Rs.7.66 Vs 1US \$ during 1973, but the economic scenario which had brought more fall in the rupee value, refer to table -1 listed on showing year wise historical changes in the Indian foreign exchange rate. Average exchange rate of Indian rupee standards at Rs.52.68 for the period ending March 2012, having depreciated the most against US dollar of Rs.53.90 Vs 1US \$ as on 23rd September 2012[4]. These one sided movement on exchange rate boosted the domestic firms which is based on export oriented businesses, and pain for importing firms which dependent on import of raw material or finished goods from the foreign country.
Table: 1 - Foreign Exchange Rate of Indian Rupee (INR) Vs US Dollar (\$)

\begin{tabular}{|c|c|c|c|c|c|}
\hline Year & INR/USD & Year & INR/USD & Year & INR/USD \\
\hline 1973 & 7.66 & 1987 & 12.95 & 2001 & 47.23 \\
1974 & 8.03 & 1988 & 13.91 & 2002 & 48.62 \\
1975 & 8.41 & 1989 & 16.21 & 2003 & 46.60 \\
1976 & 8.97 & 1990 & 17.50 & 2004 & 45.28 \\
1977 & 8.77 & 1991 & 22.72 & 2005 & 44.01 \\
1978 & 8.20 & 1992 & 28.14 & 2006 & 45.17 \\
1979 & 8.16 & 1993 & 31.26 & 2007 & 41.20 \\
1980 & 7.89 & 1994 & 31.39 & 2008 & 43.41 \\
1981 & 8.68 & 1995 & 32.43 & 2009 & 48.32 \\
1982 & 9.48 & 1996 & 35.52 & 2010 & 45.65 \\
1983 & 10.11 & 1997 & 36.36 & 2011 & 46.61 \\
1984 & 11.36 & 1998 & 41.33 & 2012 & 53.90 \\
1985 & 12.34 & 1999 & 43.12 & & \\
1986 & 12.60 & 2000 & 45.00 & & \\
\hline
\end{tabular}

Source: http://www.forecast-chart.com/usd-indian rupee.html

Foreign exchange rate of Indian currency shows historical depreciation of exchange value not only with the US dollar but also against the Pound Sterling, Euro, and Japanese Yen. The high volatile movement of these exchange rates has mostly influenced the corporate earnings and economic growth potential too the larger extend. Due to this high risk involvement in the exchange of foreign currencies, even from the early period of exchange system, this had direct impact on corporate profitability. In last 20 years, after the liberalization of the economy Indian currency have depreciated most comparatively against all the global currencies refer to figure $3,4 \& 5$.

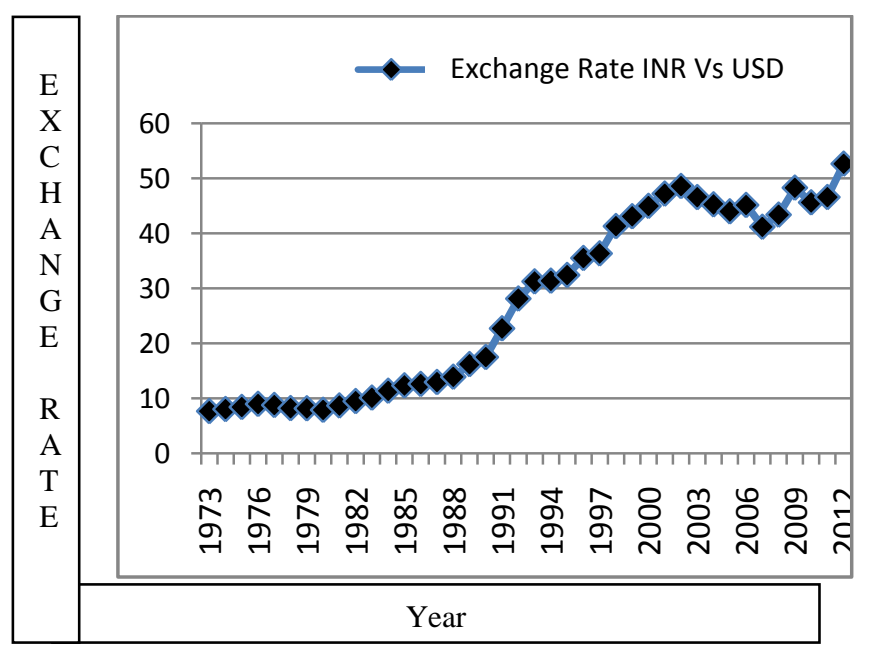

Figure: 1 - Foreign Exchange Rate of Indian Rupee (INR) Vs US Dollar 


\section{IMPACT ON CORPORATE PROFITABILITY}

The impact of foreign exchange rate volatility could influence on the economy performance and next it could be on the corporate earnings directly. The corporate earnings of the IT (Information Technology) industry depend on the exchange rate system compared with the agreed contract price and date of bill generation for the service delivered. But the question is that, does the same exchange rate exist as that of agreed contact date. It doesn't exist as that of agreed price; this might benefit either person based on the contract rate and exchange rate. The most benefited industry might be large IT and the small size firms could not bear this problem initially. Even the large scale IT firms like Infosys faces exchange rate volatility problem as their revenue comes from the US dollar, the United Kingdom Pound Sterling, Euro and from the Australian dollar, where as the firms expenses are meet through Indian rupees. The exchange rate between the rupee and the foreign currency like US dollar has major impact on the profit margin of the firm substantially. The key factors affecting the exchange rate fluctuations, mainly due to

- Country in which firm operates in the business

- Size and time of the project operation during the economic cycle

- Pricing policy of the competitors and a firm position

- Economic strength of the operating nation and visvisa

- Inflation pressure over the salary payment to the employees

- Political stability of the nation were the firm operates

- Government control over the exchange rate system

- Unanticipated move of the economic developments through political pressures

\section{A CHALLENGE ON CORPORATE PROFITABILITY}

Corporate profitability of the firm is directly linked with the exchange rate movement for the firms engaged in the foreign trade. Infosys being engaged in the foreign exports of information technology oriented services its revenue model is through foreign currency which directly influenced by the foreign exchange rate. So its profitability has correlation with the foreign exchange movement. Infosys has reported currency rate guidance for the year 2012-13 which stands around 1.60 for Great Britain Pound (GBP), 1.38 for Euro and 1.05 for Australian Dollar (AUD). Though Infosys has projected its revenue guidance on the basics of the current exchange rate trend, the years like 2008 US housing crisis had impacted on its profitability due to constant currency guidance, though rupee had sequentially depreciated.

\section{CONCLUSION}

The exchange rate fluctuations could have major implications on the corporate profits. It is an attempt to know the impact of exchange rate which could impact over the corporate profitability. Though the majority of the firms could not avoid the volatility of exchange rate scenario, this could be managed through proper hedging system adopted by the firm systematically [8]. It is a fine example how most of the IT firms operate across the globe, but they do earn in differences in the currency rate as part of their earnings [9]. All being hedged systematically and some may lead to marked to market loss which can be notional loss in the books of the accounts. In real situation, the exchange rate volatility could add high pressure on the corporate profits. So it is better to go with the circumstances and follow the global rule to get profit out the differences and volatility in the foreign exchange market. Thus it is concluded that the corporate needs to manage their foreign revenues by hedging their positions in the foreign currency future market. This strategy could improve the corporate profitability by minimizing the exchange rate risk in the foreign exchange market.

\section{REFERENCES}

[1] Ashutosh Vashishtha, and Satish Kumar, "Development of Financial Derivatives Market in India - A Case Study", International Research Journal of Finance and Economics, Issue 37, Pp.15-29, 2010

[2] Abhijeet Bhandari, " How Companies Use Derivatives for Hedging \& Risk Management", MBA Journal, Finance, www.coolavenues.com, November 15, 2010

[3] "India in the World Trading System: A Quantitive assessment", "Institute for International Economics", www.piie.com, 2003

[4] Henri Ser and Ane Tamayo, Peter Tufano, "The theory of Corporate Risk Management", Journal of Applied Corporate Finance, A Morgan Stanley Publication, Volume 21 Number 4, 2009

[5] Kumar Veetrag, "IT Industry in India: Exchange Rate Risks and Competition from China", www.veetrag.net, 2010

[6] M S Babu, K Janardhanam, and Javaid Akhter, "Forex Risk Management Practices in Selected Indian Companies", International Conference on Technology and Business Management, March 28-30 ${ }^{\text {th }}$, 2011

[7] Sudeep Jain, "Infosys Ltd: India Central Bank Urges Companies to Hedge Forex Exposure More", www.4-traders.com, 30th April 2012

[8] Pradyumna Dash "The Relationship between Interest Rate and Exchange Rate in India", Money and Finance Conference, $6^{\text {th }}$, www.oii.igidr.ac.in, $5^{\text {th }}$ June 2006

[9] Seema Menon, and K.G.Viswanathan, “ Foreign Currency Risk Management Practices in U.S Multinationals", The journal of international Business and Law, Volume 4, No.1, Pages 57-67, 2005

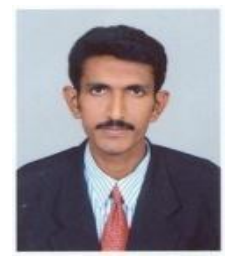

P. Sivarajadhanavel, born in Erode, Tamilnadu. He has completed BA (Economics), Bharathiyar University, Coimbatore, Tamilnadu, 2002, MBA (Finance \& Marketing) University of Madras, 2004, Chennai, Tamilnadu, M.Phil (Management), Bharathiyar University, Coimbatore, Tamilnadu, 2008. $\mathrm{He}$ has got 10 years of experience in teaching, research, and publications. He is presently working in the Department of Management Studies, Kongu Engineering College, Perundurai, Erode, Tamilnadu - 638052 , previously he has worked in Southern India Rajasthan Chamber of Commerce, Icfai University Press, K.S.R Business School. To his credit he had published 4 books, more than 25 papers in various Journals, Magazines, book chapters, and presented papers in the national and international conferences. (E-mail: sivarajadhanavel@gmail.com)

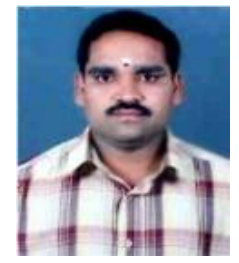

Dr.S. Chandrakumaramangalam, born in Erode, Tamilnadu. He has completed MBA, Ph.D Bharathiyar University, Coimbatore. Presently Professor, School of Management Studies, Anna University of Technology, Coimbatore, Email: ckmaucbe@ gmail.com 